\title{
Disaster Mitigation: Optimizing the Function of Executive and Legislative Institutions in Handling Covid-19
}

\author{
Anifatul Kiftiyah ${ }^{1^{*}}$ \\ ${ }^{1}$ Postgraduate Alumni of UIN Sunan Ampel Surabaya, Constitutional Law Study Program \\ Correspending Author: ${ }^{1 *}$ anifkiftiyabjob.03@gmail.com
}

\begin{abstract}
Through Presidential Decree (Keppres) Number 12 of 2020 the President has designated Covid-19 as a National Disaster. Handling Covid-19 requires good cooperation between elements, both society, government and state institutions. The President as an executive institution and the DPR as a legislative institution have very broad functions and powers in dealing with the Covid-19 pandemic. Namely, by optimizing the functions and powers it has in dealing with Covid-19 by establishing policies that aim to overcome Covid-19 without bringing political interests. This study uses a phenomenological research method with a normative juridical approach. With a descriptive analysis thinking method that aims to explain what is happening in the community and the government's anticipation in dealing with the Covid-19 pandemic. The results of this study are that the executive and legislative bodies must be more maximized and more assertive in implementing policies to deal with covid-19.
\end{abstract}

Keywords: Disaster Mitigation, Covid-19, Government and Parliament.

\section{Introduction}

2020 is an alarming year for all countries. This was caused by the emergence of a virus that originated in the city of Wuhan in China at the end of December 2019 which is called the Covid-19 virus. Until now, the virus is still a global problem of world health. Then on March 11,2020, WHO declared this outbreak a pandemic. ${ }^{1}$

Adityo Susilo, C. Martin Rumende, Ceva W Pitoyo, et.al., Corona Virus Deseas 2019: Tinjanan Literatur Terkini (Corona Virus Disease 2019: Review of Current Literatures), Jurnal Penyakit Dalam Indonesia, 2020, Vol 7 , no 1 . 
The phenomenon of the significant development of Covid-19 has caused public unrest around the world. Therefore, coordination and cooperation are needed, both on a national and international scale to be able to build public trust in preparedness in dealing with this pandemic.

In international relations, building cooperation can be done in several ways. Apart from being supported by countries with the same interests, international cooperation can be initiated by supporters of the new norm, both individually and in organizations. ${ }^{2}$ Among them there is an epistemic community, experts, academics who are knowledgeable about issues specific to their fields. ${ }^{3}$

Since the beginning of the emergence of Covid-19 in the city of Wuhan, China, Covid-19 victims have continued to experience a positive increase in virus infections and death tolls caused by this virus. Because of this incident, on January 30, 2020, WHO announced that Covid-19 needed an international handler or a Public Health Emergency of International Concern (PHEIC). In addition, WHO also issued guidelines based on the instruments of the International Health Regulation 2005 (IHR 2005) such as guidelines on surveillance and response, laboratory diagnosis, prevention and control, clinical management, and other guidelines in handling Covid-19. It is hoped that these guidelines can be adopted by other countries to prevent and deal with the spread of Covid-19.4

International Health Regulation (IHR) is an international legal instrument that regulates countries and WHO collectively in dealing with the spread of disease globally. The IHR moves through countries to inform the international community about outbreaks and receive advice and technical assistance on actions for public health. ${ }^{5}$

The emergence of covid-19 in many countries has made these countries faced with a crisis situation that makes them take drastic decisions and policies to respond to and deal with the spread of covid-19 in society. There are no definite steps yet to prevent the spread of Covid-19. Trials and errors have occurred repeatedly, but the government has not given up on trying various ways to deal

2 Finnemore, M., \& Sikkink, K. (1998). International Norm Dynamics and Political Change. International Organization, Vol. 52, No. 4, 887-917.

3 Haas, P. M. (1992). Introduction: Epistemic Communities and International Policy Coordination. International Organization, Vol. 46, No. 01, 1-35.

4 https://www.who.int/news-room/detail/30-01-2020-statement-on-the-second-meeting-of-theinternational-health-regulations-(2005)-emergency-committee-regarding-the-outbreak-of-novel-coronavirus-(2019-ncov) diakses pada 5 November 2020

5 Davies, S. E. (2019). Containing Contagion: The Politics of Disease Outbreaks in Southeast Asia. Baltimore: JHU Press. 
with covid-19. On the one hand, at the beginning of the emergence of Covid-19, many countries were still stuttering in responding to the Covid-19 pandemic. Including the country of Indonesia, it is even trapped in denial about the spread of covid-19. However, after Covid-19 began to attack Indonesia, the government took the steps and policies needed to deal with the Covid-19 pandemic.

The Covid-19 pandemic presents new challenges in all countries, because this pandemic is a different pandemic from previous pandemics such as the Spanish flu in 1918. Until now there are no standard rules to measure the preparedness of the country in facing Covid-19. However, the management that has been formulated by WHO can be used as an initial step to respond to and deal with the Covid-19 pandemic.

In Indonesia, since President Jokowi announced a positive case of Covid-19 on March 2, 2020, the Covid-19 virus has continued to spread throughout Indonesia. Therefore, on April 13, 2020, through Presidential Decree No. 12 of 2020, the President announced that Covid-19 was a national disaster. With the stipulation of this Presidential Decree, the aspects of public welfare must receive primary attention. Therefore, the urgency of this paper is how the government and the DPR as state institutions can optimally utilize their roles and authorities to deal with this pandemic.

In Indonesia, state institutions are referred to in different terms. the development of state institutions both according to theory and history regarding the organization of power and the state has had a very rapid development. ${ }^{6}$ The purpose of forming the state organization is so that the wheels of government can be implemented optimally, there is a check and balance between state institutions.

A good government system or what can be called good governance is a government system that is run by providing good services to the community, one of which is by protecting their rights including the right to information disclosure, press freedom, protection and legal certainty. In Article 28 paragraph (1) of the 1945 Constitution which reads "Setiap orang berhak atas pengakuan, jaminan, perlindungan dan kepastian hukum yang adil serta perlakuan yang sama di depan hukum".

Good governance is the process of governance in providing and providing services to the community. Meanwhile, the principles of good governance are: ${ }^{7}$

6 Jimly Asshiddiqie, Perkembangan dan Konsolidasi Lembaga Negara Pasca Reformasi, Sekretariat Jendral dan Kepaniteraan Mahkamah Konstitusi RI, Jakarta, 2006, 1.

7 Lembaga Adminstrasi Negara dan Badan Pengawasan Keuangan dan Pembangunan, 2000, Akuntabilitas Dan Good Governce”Jakarta, 23. 
1. All activities are based on an impulse demand

2. Development in community-oriented activities and the community can participate.

3. There is transparency in the administrative process and in policy making.

4. Increase effectiveness and efficiency in community services.

5. There is equality in the distribution process to those in need

The state has a very important role in dealing with this pandemic. The phenomenon of the spread of covid-19 is still a very serious problem in various countries, including Indonesia. Therefore, administrators of the constitutional system in each state institution have an important responsibility and role in handling this case. A responsive country is a country that has the ability to plan and coordinate between institutions in preparation for emergencies. Then what is the role of the state through state institutions such as the executive branch, in this case the president and the legislative body, namely the DPR, carrying out its functions and authorities in dealing with the Covid-19 pandemic. A good government system is one that can serve the people and protect their rights.

\section{Literature Review}

The occurrence of a disaster will not be separated from public policy studies, because the policy is an action that must or should not be taken by the government. In article 1 paragraph (9) of Law no. 24 of 2007 concerning Disaster Management, the definition of disaster mitigation is "an effort to reduce disaster risk, either through physical development or awareness and increased capacity to face disaster threats". Disaster mitigation is stipulated in policies that can be carried out formally and informally, the means and mechanisms in dealing with problems and selection of issues related to natural and non-natural disasters.

Currently all over the world have faced the Covid-19 pandemic. On February 11, 2020, WHO (World Health Organization) as a world health organization announced a new name for the disease caused by $2019-\mathrm{nCoV}$ to become coronavirus disease 19 or Covid-19. Regarding the virus, the International Committee on Taxonomy of Viruses has changed the previous name $2019-\mathrm{nCoV}$ 
for coronavirus- 2 syndrome or what is known as SARS-CoV-2. ${ }^{8}$ Then on March 11, 2020 the outbreak was declared a pandemic.

In dealing with this pandemic, it requires an important role from all elements, especially state institutions. In Indonesia, state institutions are referred to in different terms. the development of state institutions both according to theory and history regarding the organization of power and the state has had a very rapid development. In this case the state institutions that play the most role are the executive and legislative bodies. The relationship between the executive branch, namely the president and the legislative institution, namely the DPR, in the distribution of power, functionally, there is cooperation between the executive and legislative institutions. This can be carried out in dealing with the Covid-19 pandemic by maximizing their respective functions and authorities.

\section{Methods}

This study uses a phenomenological research method with a normative juridical approach. The object of this research is the Covid-19 pandemic disaster. The approach taken in the research object is seen from the phenomena that occur in society, then analyzed using a normative juridical approach written in law as well as the functions and authorities of the executive and legislative institutions in dealing with the Covid-19 pandemic.

From this analysis, whether the executive (President) and the legislative body (DPR) have carried out their functions and authorities optimally by establishing policies aimed at dealing with the Covid-19 pandemic. The analysis is conveyed using a descriptive analysis thinking method that aims to explain what is happening in the community and the government's anticipation in dealing with the Covid-19 pandemic.

\section{Result}

Since the emergence of the Covid-19 outbreak, all countries have experienced tremendous impacts both on social, education, health and economic impacts. The limited knowledge in overcoming this pandemic has led to the formation of cooperation by several countries in the world.

8 Gorbalenya AE, Baker SC, Baric RS, de Groot RJ, Drosten C, Gulyaeva AA, et al. Severe acute respiratory syndrome-related coronavirus: the species and its viruses - a statement of the Coronavirus Study Group. bioRxiv, 2020. 
To support the achievement of efforts in overcoming health problems, the task of WHO must be carried out by the government and policy makers in responding to policies decided by WHO because these policies can influence national policies. In this case, it is necessary to involve many experts such as scientists in the field of health, researchers, economics, law who can cooperate well without any political interest.

In implementing policies so that they can run optimally, every government agency must cooperate with each other. This paper will discuss two institutions that have played a very important role in handling Covid-19, namely the president as an executive institution and the DPR as a legislative institution.

According to Montesquieu, each country, has three branches of power arranged in a government structure, namely the legislative power that functions as an organization for the formation of laws, and power, the executive which deals with the implementation of government which is related to the application of civil law. ${ }^{9}$

Jimly Assidiqie also argues that state institutions can be divided into 3 domains, namely;

1. Executive or exercise power

2. Legislative power and supervisory function

3. Judicial power or judicial function

In this paper, we will discuss how the role of the executive body, namely the government as an implementing agency and the legislature as a supervisory agency in dealing with Covid-19.

As an effort to optimize the implementation of a policy, the policy must be supported by several aspects. George Edward III argues that there are 4 aspects that can affect the existence of policies, namely communication, sources, attitudes or behavior and bureaucratic structures. ${ }^{10}$

\subsection{The function and role of the President as an executive agency in dealing with Covid-19}

Seeing the increasinglywidespread spread of covid-19 in society, the President

9 Jimly Asshiddiqie , Menjaga Denyut Nadi Konstitusi: Refleksi Satu Tahun Mahkamah Konstitusi, Konstitusi Press, Jakarta, 2004, 60-61

${ }_{10}$ George Edward III, 1980, Implementing Public Policy. Washington DC: Congressional Quarterly Press., 9. 
and his staff, in accordance with their function as an executive institution through their authority, have issued several policies to deal with the spread of covid-19. To implement this regulation, the state must immediately establish policies on handling covid-19.

In implementing Covid-19 health services, determining policies is a very important aspect of preventing the spread of Cvid-19. Because health is an important factor for social welfare. Apart from economic factors, health is one of the factors of community welfare. both physical health and spiritual health.

Policy is a social practice. Therefore a policy is a decision that is produced through a process of discussion based on the events and conditions that occur in society. therefore the emergence of policies does not stand alone, but is based on factors that exist in society. ${ }^{11}$

In general, there are four factors that influence policy, namely the environment, the perception of policy makers about the environment, government activities regarding policies, and community activities regarding policies. ${ }^{12}$ Public policy must be presented in society as a form of state protection for citizens. Because the essence of the presence of the state is to guarantee the protection and certainty of its citizens.

To overcome the current Covid-19 pandemic, it is necessary to implement the substance of health protocols, prevention, treatment, such as regional quarantine, hospital quarantine, implementation of PSBB in each region. And in this regulation it is emphasized to provide flexibility for local governments in forming policies in accordance with conditions that occur in the community environment. Then evaluate the results of implementing policies that have been in effect in society.

The government's response in responding to the Covid-19 pandemic, the government through the National Disaster Management Agency known as BNPB issued a decree regarding the Decree of the Head of the National Disaster Management Agency No. 9A of 2020. The decree contains the Determination of the Status of Certain Emergency Disaster Outbreaks Due to Corona Virus in Indonesia. The decree was issued on January 28,2020, which states that Indonesia has declared a state of emergency for the Covid-19 pandemic disaster as in the dictum, which is valid for 32 days and from January to February 28, 2020.

11 Thoha, M. (2012). Dimensi-dimensi Prima Ilmu Administrasi Negara. Jakarta: Raja Grafindo Persada.

12 Ripley, Randal B. Policy Analysis in Political Science, Chicago: Nelson-Hal Publishers, 1985, 34-48 
Since then, Indonesia has declared its status in a state of disaster emergency within 32 days. However, the development and situation of the spread of Covid-19 is increasingly widespread, causing public panic and fear. This led to a change in BNPB's policy to extend the status of the Covid-19 pandemic emergency. The decision to extend the emergency status was issued on February 29, 2020. The extension of the Covid-19 emergency was extended until May 29, 2020.

One of the efforts made by the government to deal with covid-19 is to issue a presidential decree (Kepres) No. 9 of 2020 concerning the Task Force for the Acceleration of Handling Covid 19. In the Presidential Decree, the President ordered the governors to make appeals and regulations in their respective regions on how to deal with and anticipate the transmission of covid-19. These calls and regulations must be carried out by all elements of society by raising public awareness of the dangers of Covid-19. With the cooperation that exists between the central and regional governments, the eradication and prevention of Covid-19 will be more effective. Not only that, strict sanctions must be given to people who do not obey these regulations. The regulations and sanctions that have been established apply to all elements of society regardless of social status.

The President issued Presidential Decree No.7 of 2020 concerning the Task Force for the Acceleration of Handling of Corona Virus Diseas 2019 (Covid-19) which was set on March 13, 2020, followed by the enactment of Presidential Decree No. 9 of 2020 concerning structural changes. Article 3 of Presidential Decree No.7 of 2020 concerning the Task Force for the Acceleration of Handling Corona Virus Diseas 2019 (Covid-19) has the following objectives:

a. Increase national resilience in the health sector

b. Accelerate dealing with covid-19 by building synergies between ministries and government agencies.

c. There is increased anticipation in the development of the spread of covid-19

d. Increase operational policy making

e. Increase ability and readiness to detect and respond to covid-19.

In addition, the Government has also taken other steps, namely making the athletes' homestead as an emergency hospital. For residents of Jakarta who are indicated by Covid-19, they can be given free services to be treated at the athletes' homestead as an emergency hospital. On March 20,2020, the President issued Presidential Instruction (Inpres) No. 4 of 2020 concerning recofussing 
activities, budget reallocation, and procurement of goods and services to handle the acceleration of handling covid-19.

The government, through the Ministry of Health (Kemenkes), has taken several steps to prevent Covid-19, namely: $:^{13}$

1. Issue a circular to all health offices, the Port Health Office (KKP), the Environmental Health Engineering Center (BTKL) to always increase awareness in the face of Covid-19

2. Placing 135 thermal scanners across the airport

3. Providing health alert cards and Communication, Information, Education (IEC) to passengers

4. Designate a referral hospital as a preventive measure.

The development of covid-19 has significantly made the public even more restless. Therefore, coordination between central and local government elements is needed to build public trust in the government's response and preparedness for the handling of Covid-19. The government's response and preparedness can be seen from the strategies and policies that have been carried out by the government to detect Covid-19 early and to reduce the development of the spread of Covid-19. One of the strategies and policies carried out by the government is to establish social distancing to prevent crowds that can spread Covid-19 quickly. In addition, the government limits activities carried out outside the home, such as work from home and study from home. These efforts aim at none other than tackling the spread of covid-19 in society.

In addition, through the fatwa of the Indonesian Ulema Council (MUI) number 14 of 2020 concerning the implementation of worship in a situation where the Covid-19 outbreak occurs, the Government eliminates all religious activities and other religious activities that have the potential to gather many people who are held in places of worship such as mosques, churches, temples, monasteries, pagoda. The services referred to include Friday prayers, services, worship and Sunday mass, majlis taklim, and other holiday celebrations. Not only that, the government also recommends carrying out worship activities at home as a substitute for religious activities that have been eliminated. This regulation is in effect for 14 days after this regulation was implemented and can be extended if needed. In addition, the community is also given awareness in increasing vigilance

13 https://kemlu.go.id/hanoi/id/news/5877/langkah-dan-upaya-pemerintah-indonesia-dalam-menanganidan-menghadapi-covid-19. 
and discipline by maintaining a safe distance in interactions in order to prevent the spread of Covid-19. ${ }^{14}$

However, the government's efforts to deal with covid-19 did not go smoothly. Apart from dealing with covid-19, the government also needs to handle hoaxes about covid-19 information circulating in the community. This problem makes handling Covid-19 even more difficult. With this problem, the government is obliged to provide correct information through information disclosure. The government's efforts to foster public trust and minimize problems in society, through the Covid-19 Acceleration Task Force, the government has created a website www.covid19.go.id which can be accessed by the public as an official and accurate source in finding information about covid-19.

\subsection{The function and role of the DPR as a legislative body in dealing with Covid-19}

In Indonesia, the DPR as a legislative institution has a very important urgency in carrying out its function. There are several very strategic functions in dealing with the Covid-19 pandemic. The first function is the legislative function, which is the most essential function of the DPR institution. In an incidental situation such as at this time as a legislative institution the DPR is expected to maximize its function by discussing policies aimed at handling the Covid-19 pandemic.

The second function is the budget function. In the budget function, the DPR has discussed the transfer of the APBN function together with the executive agency so that part of the budget can be used to deal with the Covid-19 pandemic. In this case the President has issued Presidential Decree No. 54 of 2020 concerning Posture Changes in Details and the 2020 State Budget. This Presidential Regulation is a follow-up to Perppu No. 1 of 2020. The budget of several ministries is cut by Rp. 97.42 trillion. However, several Ministries experienced an increase in their budgets, such as the Ministry of Education and Culture from IDR 36 trillion to IDR 70 trillion; and the Ministry of Health from IDR 57 trillion to 76 trillion. In its implementation, the DPR has the authority to supervise the implementation of the Perpres so that the budget is used properly.

${ }^{14}$ Fatwa Majelis Ulama Indonesia (MUI) nomor 14 tahun 2020 tentang penyelenggaraan ibadah dalam situasi terjadi wabah covid-19 
The third function is supervision. The duties and powers of the DPR in the supervisory function in this situation are to supervise the implementation of laws. Looking back at the supervisory role of the DPR, the DPR has formed a Timwas (Supervisory Team) to supervise the implementation of the handling of the Covid-19 pandemic originating from all factions and commissions. In its implementation, Timwas faced many problems in the field.

One of the problems faced by Timwas was the implementation of the PSBB (Large-Scale Social Restrictions). In Permenkes 9/2020 concerning PSBB Guidelines for the Acceleration of Handling COVID-19, Large-Scale Social Restrictions as also referred to in Government Regulation Number 21 of 2020 concerning Large-Scale Social Restrictions in the Context of Accelerating Handling of Corona Virus Disease 2019 (COVID-19) occur bureaucracy that is very complicated in the PSBB process so that PSBB cannot be carried out simultaneously. In addition, the problem is that the majority of our people do not understand the importance of PSBB and there is no firm sanction for violating the PSBB, so that the PSBB cannot run effectively. In this case, Timwas can collaborate with local governments by conducting intensive supervision to limit community social activities so that the implementation of PSBB can run well. Both must synergize with each other and act decisively against PSBB violations and be supported by intensive education to the public so that people become more aware of the dangers of Covid-19.

As we know that the PSBB has not shown success with the reduction of Covid-19 victims, the government and policy makers have made a new regulation called "New Normal" which is based on the Decree of the Minister of Health Number HK.01.07 / MENKES / 328/2020 concerning Guidelines Covid-19 Prevention and Control in Office and Industrial Workplaces in Support of Business Continuity in Pandemic Situations. The change from the PSBB that has not seen the results to become a new normal is evidence that the government and its staff are not yet firm in taking action.

The DPR in its function as supervisor is by optimizing the supervision of the implementation of Decree of the Minister of Health Number HK.01.07 / MENKES / 328/2020. The decision to extend the recess period is very positive by conducting work visits in several regions to find out complaints from the community and to be able to find solutions if there are obstacles from the implementation of these decisions. The DPR can use its right of interpretation to ask the government for an explanation of policies that impact society. 
At present all countries are trying to tackle the Covid-19 pandem through policies that are formed based on the situation at hand. There is a learning policy in the formation of these policies that can be well directed and implemented. Policy learning refers to thoughts or results from new behavior or experiences and information relating to policy objectives. ${ }^{15}$ As formulated in the UGM Social and Political Sciences Policy Brief to improve the handling of Covid-19 as follows: ${ }^{16}$

1. Science and Evidence-based Policy. Namely the handling of policies based on data and time which serves to organize the next strategic steps. So that the policy is right on target.

2. Integrated policies. This step can be a good cooperation between state institutions and the central government. This policy can rebuild public trust.

3. Coordination and synergy between actors. Build coordination by releasing sectoral egos and short-term interests, both group interests and individual interests.

4. Policies to strengthen infrastructure availability. Area-based infrastructure readiness needs to be structured so that all areas are ready to cope with this pandemic. Such as the existence of a place to accommodate patients apart from the hospital, the availability of an ambulance, and other infrastructure.

With the existence of policy learning in making policies, it is hoped that the resulting policies will be policies that are in the interests of the community. Policies and those carried out by the government and the DPR are one of the mitigation efforts in the face of Covid-19. Through its function the DPR has a very strategic role in handling this pandemic. The public hopes that the government and policy makers will act more decisively and seriously by prioritizing matters relating to the handling of the Covid-19 pandemic.

The central government, regional governments and the DPR as policy supervisors should be firm in implementing policies. That the policy is applicable to be obeyed by all people. Likewise, in implementing policy sanctions, these

${ }^{15}$ Weible, C.M. \& T. Heikkila (2017) “Policy Conflict Framework”, Policy Sci (2017) 50:23-40 DOI 10.1007/s11077-017-9280-6.

${ }^{16}$ Mas'udi, Wawan \&Astrina, Azifah (2020a). "Problematika Kebijakan Krisis COVID-19 di Indonesia”. Policy Brief. Edisi1. Yogyakarta: FISIPOL UGM., Mas'udi,Wawan \& Astrina, Azifah(2020b)."Dari Krisis Koordinasi menuju Koordinasi Krisis: Penanganan COVID-19 di Indonesia”. Policy Brief. Edisi 2. Yogyakarta: FISIPOL UGM. 
sanctions must be fair, not sharp downward and blunt upward. Because if this happens, new problems will arise in the community.

The President has issued several policies aimed at dealing with the spread of covid-19. In implementing this policy, the DPR as a supervisory body must be able to properly oversee the implementation of the policy in society. one of them is by alerting local governments and stakeholders to become bullies in preventing the spread of covid-19 in the surrounding environment. The best step to take to prevent the spread of Covid-19 is to stay at home. And if forced to leave the house, you must comply with the health protocol set by the government by using a mask, keeping your distance and washing your hands diligently. Because as we know that in Covid-19 there are patients without symptoms or without interference.

\section{Conclussion}

Covid-19 has caused crises in many countries. Almost all countries in the world face uncertainty in dealing with Covid-19. They face difficulties in governance, handling policies and problem solving in the face of Covid-19. Covid-19 not only threatens public health, but the global economy. Indonesia itself experiences uncertainty in handling Covi-19. There are many obstacles, such as health service constraints, the minimum APBD, to the very standard crisis management. Thus the government is trying to make various policies to deal with the Covid-19 pandemic. In overcoming the pandemic, good cooperation between elements is needed.

Covid-19 has been determined to be a national disaster through Presidential Decree No. 12 of 2020. One of the mitigation processes carried out is through good coordination and synergy in order to create the right policies and actions to deal with Covid-19. In addition, it requires high public awareness to always implement health protocols. Thus there will be synchronization in handling Covid-19 which greatly affects policy making and implementation. At the country level, horizontal and vertical synergies between state institutions are an important element in overcoming this pandemic. The public hopes that the President and his staff and the DPR can optimize their performance as a form of mitigation process in handling Covid-19, instead of discussing policies and doing things outside of handling this pandemic. Because the biggest hope of the community at this time is that the Covid-19 pandemic will end soon. 


\section{Reference}

Adityo Susilo, C. Martin Rumende, Ceva W Pitoyo, et.al., 2020, Corona Virus Deseas 2019: Tinjauan Literatur Terkini (Corona Virus Disease 2019: Review of Current Literatures), Jurnal Penyakit Dalam Indonesia, Vol 7, no 1.

Davies, S. E. (2019). Containing Contagion: The Politics of Disease Outbreaks in Southeast Asia. Baltimore: JHU Press.

Fatwa Majelis Ulama Indonesia (MUI) nomor 14 tahun 2020 tentang penyelenggaraan ibadah dalam situasi terjadi wabah covid-19

Finnemore, M., \& Sikkink, K. (1998). International Norm Dynamics and Political Change. International Organization, Vol. 52, No. 4, 887-917.

George Edward III, 1980, Implementing Public Policy. Washington DC: Congressional Quarterly Press..

Gorbalenya AE, Baker SC, Baric RS, de Groot RJ, Drosten C, Gulyaeva AA, et al. Severe acute respiratory syndrome-related coronavirus: the species and its viruses-a statement of the Coronavirus Study Group. bioRxiv 2020 Feb 11

Haas, P. M. (1992). Introduction: Epistemic Communities and International Policy Coordination. International Organization, Vol. 46, No. 01, 1-35.

https://kemlu.go.id/hanoi/id/news/5877/langkah-dan-upaya-pemerintahindonesia-dalam-menangani-dan-menghadapi-covid-19 accessed on 6 Desember 2020.

Asshiddiqie, Jimly, 2004. Menjaga Denyut Nadi Konstitusi: Refleksi Satu Tahun Mahkamah Konstitusi. Konstitusi Press. Jakarta. , 2006. Perkembangan dan Konsolidasi Lembaga Negara Pasca Reformasi, Sekretariat Jendral dan Kepaniteraan Mahkamah Konstitusi RI. Jakarta.

Lembaga Adminstrasi Negara dan Badan Pengawasan Keuangan dan Pembangunan, 2000, Akuntabilitas Dan Good Governce'Jakarta.

Mas'udi, Wawan \& Astrina, Azifah,.2020b, Dari Krisis Koordinasi Menuju Koordinasi Krisis: Penanganan COVID-19 di Indonesia. Policy Brief. Edisi 2. Yogyakarta: FISIPOL UGM.

Mas'udi, Wawan \& Astrina, Azifah., 2020a. Problematika Kebijakan Krisis COVID-19 di Indonesia. Policy Brief. Edisi1. Yogyakarta: FISIPOL UGM. Ripley, Randal B,. 1985. Policy Analysis in Political Science, Chicago: Nelson-Hal Publishers. 
Thoha, M. 2012. Dimensi-dimensi Prima Ilmu Administrasi Negara. Jakarta: Raja Grafindo Persada.

Weible, C.M. \& T. Heikkila,. 2017,Policy Confict Framework, Policy Sci (2017) 50:23-40 DOI 10.1007/s11077-017-9280-6.

WorldHealthOrganization.Retrievedfrom Institut Montaigne. https://www. institutmontaigne.org/en/blog/fighting-coronavirus-pandemic-chinasinfluence-world-health-organization 2020 
